\title{
SYNTHESIS OF SCHIFF BASE AS DNA GYRASE B INHIBITOR, ANTIBACTERIAL, ANTI-INFLAMMATORY AND ANTIOXIDANT AGENTS
}

\author{
Pradeep Kate ${ }^{1}$, Shashikant Gaikwad ${ }^{2}$, Tukaram Lokhande ${ }^{2}$, Abdul Shaikh ${ }^{2}$, \\ Babasaheb Sonawane ${ }^{1}$, Praffula Choudhari ${ }^{3}$ and Madhusudan Bachute ${ }^{1^{*}}$ \\ ${ }^{1}$ Department of Chemistry, Karmaveer Bhaurao Patil Mahavidyalaya, \\ Pandharpur-413304, Maharashtra, INDIA \\ ${ }^{2}$ Chemistry Research Laboratory, Department of Chemistry, Shri Shivaji Mahavidyalaya, \\ Barshi-413401, Maharashtra, INDIA \\ ${ }^{3}$ Department of Pharmaceutical Chemistry, Bharati Vidyapeeth College of Pharmacy, \\ Kolhapur-416001, Maharashtra, INDIA \\ *E-mail : mbachute@gmail.com
}

\begin{abstract}
A series of some 4-\{[(Z)-(1,3-diphenyl-1H-pyrazole-4-yl)methylidene $]$ amino $\}$-5-methyl-4H-1,2,4-triazole-3-thiols were synthesized by reaction of substituted 1,3-diphenyl- $1 H$-pyrazole-4-carbaldehyde with 4-amino-5-methyl- $4 H$ 1,2,4-triazole-3-thiol in acidic medium. The synthesized compounds were characterized by ${ }^{1} \mathrm{H} \mathrm{NMR},{ }^{13} \mathrm{C}$ NMR, IR and mass spectroscopic techniques. The products were obtained in high yield and were screened for antiinflammatory, antioxidant and antibacterial activities against various pathogenic bacteria. Compound EP 8 (71.55\%) and EP 10 (74.31\%) exhibited excellent anti-inflammatory activity while compound EP $5(56.87 \%)$ and EP 8 $(52.50 \%)$ exhibited good antioxidant activity. Molecular docking study exhibited the possible mode of action of synthesized derivatives by inhibition of DNA gyrase $B$.

Keywords: Triazolethiol, DNA gyrase B inhibitor, Molecular docking, Schiff base, anti-inflammatory, antioxidant activity
\end{abstract}

(C) RASĀYAN. All rights reserved

\section{INTRODUCTION}

Nitrogen containing heterocycles constitute the major portion of chemical entities, which are part of many biologically active pharmaceuticals, fine chemicals, natural products and play a vital role in increasing the quality of life. ${ }^{1}$ The compound 1, 2, 4-triazole and its derivatives were reported to show various pharmacological applications like antimicrobial, anticancer, antioxidant, anti-inflammatory and analgesic properties. ${ }^{2-5}$ They have other applications such as dyes, lubricants and analytical reagents. ${ }^{6}$ Nowadays, drugs like alprazolam (anxiolytic agent), itraconazole (an antifungal agent), rizatriptan (antimigraine agent), fluconazole and ribavirin (antiviral agent) are the best examples of effective molecules with triazole nucleus.

Further, the pyrazole derivatives also reported exhibiting diverse biological activities.$^{7-9}$ During the last few decades a significant number of new species with a wide range of biological activities (e.g. anticancer, antimicrobial etc.) and low cytotoxicity have been reported. This is due to the fact that pathogens frequently undergo mutations and exhibit the resistance to the particular antibiotics. ${ }^{10-12}$ Recently, there has been significant progress in 1, 3-diarylpyrazole chemistry. ${ }^{13-20}$

The derivatives of 4-amino-5-methyl-4H-1,2,4-triazole-3-thiol are ultimate heterocyclic compounds by virtue of the presence of vicinal amino and mercapto groups. These constitute a ready-made building block for construction of various organic heterocycles. ${ }^{21}$ Schiff bases and their metal complexes derived

Rasayan J. Chem., 11(4), 1441-1450(2018)

http://dx.doi.org/10.31788/RJC.2018.1143080

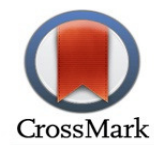


from 3-substituted-4-amino-5-mercapto-1, 2, 4-triazoles exhibit remarkable anti-breast cancer, antiinflammatory, analgesic, antidepressant, antimicrobial activities ${ }^{22,23}$ and they are useful analytical reagents ${ }^{24-27}$.

In view of medicinal and biological properties of 3-substituted-4-amino-5-mercapto-1, 2, 4-triazoles, substituted pyrazoles; we thought that the combination of these moieties would result in enhanced biological activities. There is no report on condensation of 1,3-diphenyl-1H-pyrazole-4-carbaldehyde with 4-amino-5-methyl-4H-1, 2, 4-triazole-3-thiols to form Schiff bases using methanol and acetic acid.

In the present article, we report the synthesis of a series of biologically active Schiff bases achieved through condensation of 3-substituted-4-amino-5-mercapto-1, 2, 4-triazole with substituted 1, 3-diphenyl$1 H$-pyrazole-4-carbaldehydes. The synthesized Schiff bases were characterized by different spectral techniques. The modes of active binding sites for biological activities were studied by molecular docking.

\section{Materials and Reagents}

\section{EXPERIMENTAL}

All the chemicals were purchased from a commercial supplier, Research Lab Chemicals, Mumbai. Substituted acetophenones (99\% pure, LR grade), methanol and DMF (Merck, $99 \%$ ) were used without further purification. Phenyl hydrazine and hydrazine hydrate (Sigma Aldrich, 98\%) were used after distillation. Precoated silica aluminium plates of Merck were used for TLC.

\section{Characterization}

Melting points of synthesized compounds were taken by open tube capillary method and are uncorrected. The ${ }^{1} \mathrm{H}$ NMR spectra were recorded on a Bruker $400 \mathrm{MHz}$ spectrophotometer using tetramethylsilane (TMS) as an internal standard. The IR spectra were recorded on Thermo Fisher IR instrument by ATR technique. The mass spectra were recorded on Thermo Scientific Q-Exactive, Accela 1250 pump. The completion of reaction and purity of the synthesized compounds were checked by TLC using a proper proportion of petroleum ether and ethyl acetate as solvent.

\section{General Procedure for Synthesis of Schiff Bases (EP 1- EP 10)}

1, 3-diphenyl-1 $H$-pyrazole-4-carbaldehydes (1) were synthesized from 1-phenylethane-1-one using literature procedure ${ }^{28}$. 4-Amino-5-methyl-4H-1, 2, 4-triazole-3-thiol (2) was synthesized from hydrazine hydrate, carbon disulphide and acetic acid ${ }^{29}$. 1,3-diphenyl- $1 \mathrm{H}$-pyrazole-4-carbaldehyde $(1 \mathrm{mmol})$ and 4 amino-5-methyl-4H-1, 2, 4-triazole-3-thiol $(1 \mathrm{mmol})$ were condensed by refluxing them for 3-4 $\mathrm{h}$ in methanol $(20 \mathrm{~mL})$ in the presence of acetic acid (Scheme-1). The reaction was monitored by TLC (PE:EA-3:1). After completion of the reaction, the mixture was poured on crushed ice. The solid product separated out was recrystallized from ethanol. The physical data is represented in Table-2.

\section{Spectroscopic Data of Synthesized Compounds}

\section{5-methyl-4-[(Z)-\{[3-(4-nitrophenyl)-1-phenyl-1H-pyrazol-4yl]methylidene\}amino]-4H-1,2,4-} triazole-3-thiol (3)

(EP 1, $\mathrm{C}_{19} \mathrm{H}_{15} \mathrm{~N}_{7} \mathrm{O}_{2} \mathrm{~S}$ ).m.p.:259-260 ${ }^{\circ} \mathrm{C}$; IR ( $\left.\mathrm{cm}^{-1}\right)$ : 3043 (C-H str.), 1618 (CH=N str.), 1027 (C-S str.), 845 (Ar-H str.), $1340\left(-\mathrm{NO}_{2}\right), 2746$ (-SH); ${ }^{1} \mathrm{H}$ NMR (DMSO-d $\left.6,400 \mathrm{MHz}\right): \delta=2.3\left(\mathrm{~s}, 3 \mathrm{H}, \mathrm{CH}_{3}\right), 7.7-7.8$ $(\mathrm{m}, 5 \mathrm{H}, \mathrm{Ar}-\mathrm{H}), 7.3-7.5(\mathrm{~m}, 4 \mathrm{H}, \mathrm{Ar}-\mathrm{H}), 10.2(\mathrm{~s}, 1 \mathrm{H}, \mathrm{N}=\mathrm{CH}), 8.8(\mathrm{~s}, 1 \mathrm{H}$ of pyrazole $), 13.5(\mathrm{~s}, 1 \mathrm{H}, \mathrm{SH}){ }^{13} \mathrm{C}$ NMR (100 MHz, DMSO): 11.1, 115.4, 119.4, 123.0, 127.7, 128.6, 129.6, 130.3, 130.8, 131.7, 139.1, $148.5,152.5,155.1,161.4 ; \mathrm{HRMS} \mathrm{m} / \mathrm{z}(\mathrm{M}+\mathrm{H})^{+}: 405.4$; found 406.1 .

\section{4-[(Z)-\{[3-(4-Bromophenyl)-1-phenyl-1H-pyrazol-4yl]methylidene\}amino]-5-methyl-4H-1,2,4- triazole-3-thiol}

(EP 2, $\mathrm{C}_{19} \mathrm{H}_{15} \mathrm{BrN}_{6} \mathrm{~S}$ ), m.p.: 242-244 ${ }^{\circ} \mathrm{C}$; IR $\left(\mathrm{cm}^{-1}\right)$ : 3102(C-H str.), 1608 (CH=N str.), 1007 (C-S str.), 755 (Ar-H str.); ${ }^{1} \mathrm{H}$ NMR (DMSO-d $\left.6,400 \mathrm{MHz}\right): \delta 2.3\left(\mathrm{~s}, 3 \mathrm{H}, \mathrm{CH}_{3}\right), 7.7-7.8(\mathrm{~m}, 5 \mathrm{H}, \mathrm{Ar}-\mathrm{H}), 7.3-7.5(\mathrm{~m}$, $4 \mathrm{H}, \mathrm{Ar}-\mathrm{H}), 10.2(\mathrm{~s}, 1 \mathrm{H}, \mathrm{N}=\mathrm{CH}), 8.7(\mathrm{~s}, 1 \mathrm{H}$ of pyrazole $), 13.5(\mathrm{~s}, 1 \mathrm{H}, \mathrm{SH}) ;{ }^{13} \mathrm{C}$ NMR (100 MHz, DMSO): 11.1, 115.4, 119.4, 123.0, 127.7, 128.6, 129.6, 130.3, 130.8, 131.7, 139.1, 148.5, 152.5, 155.1, 161.4; HRMS m/z $(\mathrm{M}+\mathrm{H})^{+}:$439.3; found 441.0. 
4-\{(Z)-[(1,3-Diphenyl-1H-pyrazol-4-yl)methylidene]amino\}-5-methyl-4H-1,2,4-triazole-3-thiol (EP 3, $\mathrm{C}_{19} \mathrm{H}_{16} \mathrm{~N}_{6} \mathrm{~S}$ ), m.p.: 228-229 ${ }^{\circ} \mathrm{C}$; IR ( cm $\left.{ }^{-1}\right): 2980$ (C-H str.), 1607 (CH=N str.), 1015 (C-S str.), 809 (Ar-H str.); ${ }^{1} \mathrm{H}$ NMR (DMSO-d $\left.6,400 \mathrm{MHz}\right): \delta 2.3\left(\mathrm{~s}, 3 \mathrm{H}, \mathrm{CH}_{3}\right), 6.9-7.3(\mathrm{~m}, 5 \mathrm{H}, \mathrm{Ar}-\mathrm{H}), 7.4-7.7$ (m, 4H, $\mathrm{Ar}-\mathrm{H}), 10.1$ (s, 1H,N=CH), 8.5 (s,1H of pyrazole), 12.7 (s, 1H, SH); ${ }^{13} \mathrm{C}$ NMR (100 MHz, DMSO): 11.1, $115.4,119.4,127.5,128.4,128.7,128.7,128.9,129.6,131.7,139.1,148.5,149.2,153.7,155.6,161.5$, 165.8, HRMS m/z $(\mathrm{M}+\mathrm{H})^{+}: 360.4$; found 361.1.

\section{4-[(Z)-\{[3-(4-Methoxyphenyl)-1-phenyl-1H-pyrazol-4yl]methylidene\}amino]-5-methyl-4H-1,2,4- triazole-3-thiol}

(EP 4, $\left.\mathrm{C}_{20} \mathrm{H}_{18} \mathrm{~N}_{6} \mathrm{OS}\right)$, m.p.: 216-218 ${ }^{\circ} \mathrm{C}$; IR $\left(\mathrm{cm}^{-1}\right): 3100(\mathrm{C}-\mathrm{H}$ str), 1605 (CH=N str), 1019 (C-S str), 807 (Ar-H str); ${ }^{1} \mathrm{H}$ NMR (DMSO-d $\left.6,400 \mathrm{MHz}\right): \delta 2.3\left(\mathrm{~s}, 3 \mathrm{H}, \mathrm{CH}_{3}\right), 3.8\left(\mathrm{~s}, 3 \mathrm{H}, \mathrm{OCH}_{3}\right), 7.7-8.5(\mathrm{~m}, 5 \mathrm{H}, \mathrm{Ar}-\mathrm{H})$, 7.2-7.5 $(\mathrm{m}, 4 \mathrm{H}, \mathrm{Ar}-\mathrm{H}), 10.2(\mathrm{~s}, 1 \mathrm{H}, \mathrm{N}=\mathrm{CH}), 8.5(\mathrm{~s}, 1 \mathrm{H}$ of pyrazole $), 12.8(\mathrm{~s}, 1 \mathrm{H}, \mathrm{SH}) ;{ }^{13} \mathrm{C}$ NMR $(100$ MHz, DMSO): 11.1, 55.3, 114.2, 115.2, 119.5, 124.0, 127.4, 127.6, 129.5, 130.0, 139.2, 148.5, 154.1, 156.3, 160.2, 161.6,HRMS m/z $(\mathrm{M}+\mathrm{H})^{+}: 390.4$; found 391.1 .

\section{4-(4-\{(Z)-[(3-Methyl-5-sulfanyl-4H-1,2,4-triazol-4-yl)imino]methyl\}-1-phenyl-1H-pyrazol-3- yl)phenol}

(EP 5, $\left.\mathrm{C}_{19} \mathrm{H}_{16} \mathrm{~N}_{6} \mathrm{OS}\right)$, m.p.: $250-252^{\circ} \mathrm{C}$; IR $\left(\mathrm{cm}^{-1}\right)$ : 3147 (C-H str), $1588(\mathrm{CH}=\mathrm{N}$ str), 1056 (C-S str), 834 (Ar-H str); ${ }^{1} \mathrm{H}$ NMR (DMSO-d $\left.6,400 \mathrm{MHz}\right): \delta 2.1\left(\mathrm{~s}, 3 \mathrm{H}, \mathrm{CH}_{3}\right), 7.3-7.4(\mathrm{~m}, 5 \mathrm{H}, \mathrm{Ar}-\mathrm{H}), 7.6-7.8(\mathrm{~m}, 4 \mathrm{H}$, $\mathrm{Ar}-\mathrm{H}), 10.1(\mathrm{~s}, 1 \mathrm{H}, \mathrm{N}=\mathrm{CH}), 8.5(\mathrm{~s}, 1 \mathrm{H}$ of pyrazole $), 8.6(\mathrm{~s}, 1 \mathrm{H}, \mathrm{OH}), 12.7(\mathrm{~s}, 1 \mathrm{H}, \mathrm{SH}) ;{ }^{13} \mathrm{C} \mathrm{NMR}(100 \mathrm{MHz}$, DMSO): 11.1, 115.0, 115.8, 119.3, 122.62, 127.4, 127.7, 129.5, 129.9, 139.2, 148.4, 154.3, 156.3., 158.3, 161.5, HRMS m/z $(\mathrm{M}+\mathrm{H})^{+}$: 376.4; found 377.1.

\section{5-Methyl-4-[(Z)-\{[3-(4-methylphenyl)-1-phenyl-1H-pyrazol-4-yl]methylidene\}amino]-4H-1,2,4- triazole-3-thiol \\ (EP 6, $\mathrm{C}_{20} \mathrm{H}_{18} \mathrm{~N}_{6} \mathrm{~S}$ ) , m.p.: 231-232 ${ }^{\circ} \mathrm{C}$; IR ( $\left.\mathrm{cm}^{-1}\right)$ :2931 (C-H str.), 1607 (CH=N str.), 1051 (C-S str.), 820 (Ar-H str.); ${ }^{1} \mathrm{H}$ NMR (DMSO-d $\left.6,400 \mathrm{MHz}\right): \delta 2.3\left(\mathrm{~s}, 3 \mathrm{H}, \mathrm{CH}_{3}\right), 2.4\left(\mathrm{~s}, 3 \mathrm{H}, \mathrm{CH}_{3}\right), 7.2-7.4(\mathrm{~m}, 5 \mathrm{H}, \mathrm{Ar}-\mathrm{H})$, 7.6-7.7 (m, 4H, Ar-H), $10.1(\mathrm{~s}, 1 \mathrm{H}, \mathrm{N}=\mathrm{CH}), 8.5\left(\mathrm{~s}, 1 \mathrm{H}\right.$ of pyrazole), $13.0(\mathrm{~s}, 1 \mathrm{H}, \mathrm{SH}) ;{ }^{13} \mathrm{C}$ NMR $(100$ MHz, DMSO): 10.7, 115.4, 119.4, 127.6, 128.8, 129.0, 129.7, 130.1, 130.4, 134.5, 139.1, 148.4, 149.1, 152.3, 155.2, 161.4, 165.7; HRMS m/z $(\mathrm{M}+\mathrm{H})^{+}$: 374.4; found 375.1.}

\section{4-[(Z)-\{[3-(4-Fluorophenyl)-1-phenyl-1H-pyrazol-4-yl]methylidene $\}$ amino]-5-methyl-4H-1,2,4- triazole-3-thiol}

(EP 8, $\mathrm{C}_{19} \mathrm{H}_{15} \mathrm{FN}_{6} \mathrm{~S}$ ), m.p.: 227-229 ${ }^{\circ} \mathrm{C}$; IR (cm $\left.{ }^{-1}\right)$ : 2975(C-H str.), 1604 (CH=N str), 1020 (C-S str.), 800 (Ar-H str.); ${ }^{1} \mathrm{H}$ NMR (DMSO-d $\left.6,400 \mathrm{MHz}\right): \delta 2.3\left(\mathrm{~s}, 3 \mathrm{H}, \mathrm{CH}_{3}\right), 7.7-7.8(\mathrm{~m}, 5 \mathrm{H}, \mathrm{Ar}-\mathrm{H}), 7.4-7.5(\mathrm{~m}, 4 \mathrm{H}$, $\mathrm{Ar}-\mathrm{H}), 10.2(\mathrm{~s}, 1 \mathrm{H}, \mathrm{N}=\mathrm{CH}), 8.7$ (s,1H of pyrazole), 13.5 (s, 1H, SH); ${ }^{13} \mathrm{C}$ NMR (100 MHz, DMSO): 11.1, $115.3,115.5,115.8,119.4,127.6,128.1,128.8,129.6,130.6,130.7,139.1,148.4,152.6,155.4,161.4$, 164.4; HRMS m/z $(\mathrm{M}+\mathrm{H})^{+}$: 378.4; found 379.1.

4-[(Z)-\{[3-(4-Chlorophenyl)-1-phenyl-1H-pyrazol-4-yl]methylidene\}amino]-5-methyl-4H-1,2,4triazole-3-thiol

(EP 9, $\mathrm{C}_{19} \mathrm{H}_{15} \mathrm{ClN}_{6} \mathrm{~S}$ ), m.p.: 266-268 ${ }^{\circ} \mathrm{C}$; IR $\left(\mathrm{cm}^{-1}\right)$ : 3102(C-H str.), 1609 (CH=N str.), 1006 (C-S str.), 819 (Ar-H str); ${ }^{1} \mathrm{H}$ NMR (DMSO-d $\left.6,400 \mathrm{MHz}\right): \delta 2.3\left(\mathrm{~s}, 3 \mathrm{H}, \mathrm{CH}_{3}\right), 7.7-7.8(\mathrm{~m}, 5 \mathrm{H}, \mathrm{Ar}-\mathrm{H})$, 7.3-7.5 (m, $4 \mathrm{H}, \mathrm{Ar}-\mathrm{H}), 10.2(\mathrm{~s}, 1 \mathrm{H}, \mathrm{N}=\mathrm{CH}), 8.7(\mathrm{~s}, 1 \mathrm{H}$ of pyrazole $), 13.5(\mathrm{~s}, 1 \mathrm{H}, \mathrm{SH}) ;{ }^{13} \mathrm{C}$ NMR $(100 \mathrm{MHz}, \mathrm{DMSO}):$ $11.1,119.4,123.0,127.7,128.6,129.6,130.3,130.8,131.7,139.1,148.5,155.1,161.4 ; \mathrm{HRMS} \mathrm{m} / \mathrm{z}(\mathrm{M}+$ $\mathrm{H})^{+}$: 394.8; found 394.0.

\section{5-Methyl-4-[(Z)-\{[3-(3-nitrophenyl)-1-phenyl-1H-pyrazol-4-yl]methylidene\}amino]-4H-1,2,4- triazole-3-thiol}

(EP 10, $\mathrm{C}_{19} \mathrm{H}_{15} \mathrm{~N}_{7} \mathrm{O}_{2} \mathrm{~S}$ ), m.p.: 215-217 ${ }^{\circ} \mathrm{C}$; IR ( cm $\left.{ }^{-1}\right)$ : 3102(C-H str.), 1608 (CH=N str.), 1007 (C-S str.), 755 (Ar-H str.); ${ }^{1} \mathrm{H}$ NMR (DMSO-d $\left.6,400 \mathrm{MHz}\right): \delta 2.3\left(\mathrm{~s}, 3 \mathrm{H}_{1} \mathrm{CH}_{3}\right), 7.7-7.8(\mathrm{~m}, 5 \mathrm{H}, \mathrm{Ar}-\mathrm{H}), 7.3-7.5$ (m, $4 \mathrm{H}, \mathrm{Ar}-\mathrm{H}), 10.2(\mathrm{~s}, 1 \mathrm{H}, \mathrm{N}=\mathrm{CH}), 8.7(\mathrm{~s}, 1 \mathrm{H}$ of pyrazole $), 13.5(\mathrm{~s}, 1 \mathrm{H}, \mathrm{SH}) ;{ }^{13} \mathrm{C}$ NMR (100 MHz, DMSO): 
$11.1,115.4,119.4,123.0,127.7,128.6,129.6,130.3,130.8,131.7,139.1,148.5,152.5,155.1,161.4$; HRMS m/z $(\mathrm{M}+\mathrm{H})^{+}$: 405.4; found 406.1.

\section{Chemistry}

\section{RESULTS AND DISCUSSION}

To optimize the most appropriate parameters such as solvent, amount of catalyst, reaction temperature and reaction time we have investigated the reaction of 3-(4-nitrophenyl)-1-phenyl-1 $\mathrm{H}$-pyrazole-4carbaldehyde (1) with 4-amino-5-methyl-4H-1, 2, 4-triazole-3-thiol (2) to afford the title compound 5methyl-4-[(Z)-\{[3-(4-nitrophenyl)-1-phenyl-1H-pyrazol-4-yl]methylidene $\}$ amino]-4H-1,2,4-triazole-3-

thiol (3). The reactions were carried out under different catalytic as well as solvent conditions and the results are summarized in Table-1. After optimization of reaction conditions, various aldehydes were used in this multi-component condensation reaction. Table-1 (entries 10 and 11) shows that condensation in methanol as a solvent in the presence of acetic acid or $\mathrm{H}_{2} \mathrm{SO}_{4}$ as catalyst led to an excellent yield of the desired product.

Table-1: Optimization of Reaction Condition for the Synthesis of 5-methyl-4-[(Z)-\{[3-(4-nitrophenyl)-1-phenyl-1Hpyrazol-4yl]methylidene \}amino]-4H-1,2,4-triazole-3-thiol.

\begin{tabular}{c|c|c|c|c}
\hline Entry & Catalyst & Solvent & Time $(\mathrm{h})$ & Yield $^{\mathrm{b}}(\%)$ \\
\hline 1 & - & $99.9 \%$ EtOH & $5-6$ & - \\
\hline 2 & - & Toluene & $2-3$ & - \\
\hline 3 & $5 \mathrm{~mol} \% \mathrm{CA}$ & $\mathrm{H}_{2} \mathrm{O}$ & $3-4$ & - \\
\hline 4 & $5 \mathrm{~mol} \% \mathrm{CA}$ & $50 \% \mathrm{C}_{2} \mathrm{H}_{5} \mathrm{OH}$ & $3-4$ & $\mathrm{~T}_{\mathrm{c}}$ \\
\hline 5 & $5 \mathrm{~mol} \mathrm{CA}$ & $99.9 \%$ EtOH & $5-6$ & $\mathrm{~T}_{\mathrm{c}}$ \\
\hline 6 & $\mathrm{H}_{2} \mathrm{SO}_{4}$ & $\mathrm{H}_{2} \mathrm{O}$ & $5-6$ & - \\
\hline 7 & $\mathrm{H}_{2} \mathrm{SO}_{4}$ & $50 \%$ EtOH & $7-8$ & 45 \\
\hline 8 & $\mathrm{H}_{2} \mathrm{SO}_{4}$ & $99.9 \%$ EtOH & $4-5$ & $65-85$ \\
\hline 9 & $\mathrm{CH}_{3} \mathrm{COOH}_{2}$ & $99.9 \%$ EtOH & $4-5$ & $69-85$ \\
\hline 10 & $\mathrm{H}_{2} \mathrm{SO}_{4}$ & Methanol & $3-4$ & $72-86$ \\
\hline 11 & $\mathrm{CH}_{3} \mathrm{COOH}$ & Methanol & $3-4$ & $73-86$ \\
\hline
\end{tabular}

$\mathrm{T}_{\mathrm{c}^{-}}$Trace amount, CA- Citric acid

b Isolated yield

It was found that when the reaction is carried out in various solvents without catalyst the conversion of starting material into the product was not observed even after heating for 5-6 h (Table-1,entries 1and 2) indicating the need of a catalyst for the reaction. In presence of citric acid or sulphuric acid as a catalyst in water, the product was not obtained (Table-1,entries 3 and 6), but in the presence of citric acid as a catalyst in $50 \%$ ethanol or $99.9 \%$ ethanol gave trace amount of product (Table-1, entries 4 and 5). In the presence of sulphuric acid catalyst and $50 \%$ ethanol as a solvent, the reaction afforded a moderate yield of product (Table-1, entry 7). A good yield of the product was obtained when the reaction was performed in absolute ethanol in presence of sulphuric acid as a catalyst (Table-1, entry 8). Further, a good yield of product was obtained when the reaction was carried out in presence of acetic acid as a catalyst in absolute alcohol (Table-1, entry 9).

In view of green practice, we had used acetic acid as less hazardous catalyst and methanol as a solvent. Synthesized compounds were characterized by spectral techniques such as ${ }^{1} \mathrm{H} N M R,{ }^{13} \mathrm{C}$ NMR, IR, mass spectroscopy. Yields of the products range between 70 to $85 \%$. Physical constants and yields are recorded in Table-2.

Table- 2: Physical Data for Derivative of 4-amino-5-methyl-4H-1, 2, 4-triazole-3-thiol

\begin{tabular}{c|c|c|c|c|c|c|c|c}
\hline $\begin{array}{c}\text { S. } \\
\text { No. }\end{array}$ & Product & $\mathrm{R}$ & $\mathrm{R}^{\prime}$ & Molecular formula & $\begin{array}{c}\text { Molecular } \\
\text { weight }\end{array}$ & $\begin{array}{c}\text { Time in } \\
\text { a min. }\end{array}$ & $\begin{array}{c}\text { Yield } \\
\%\end{array}$ & $\begin{array}{c}\text { mp }\left({ }^{\circ} \mathrm{C}\right) \\
\text { Found }\end{array}$ \\
\hline 1 & EP 1 & $4-\mathrm{NO}_{2}$ & $\mathrm{CH}_{3}$ & $\mathrm{C}_{19} \mathrm{H}_{15} \mathrm{~N}_{7} \mathrm{O}_{2} \mathrm{~S}$ & 405.4 & 180 & 82.84 & $259-260$ \\
\hline 2 & EP 2 & $4-\mathrm{Br}$ & $\mathrm{CH}_{3}$ & $\mathrm{C}_{19} \mathrm{H}_{15} \mathrm{BrN}_{6} \mathrm{~S}$ & 439.3 & 180 & 77.62 & $242-244$ \\
\hline 3 & EP 3 & $\mathrm{H}$ & $\mathrm{CH}_{3}$ & $\mathrm{C}_{19} \mathrm{H}_{16} \mathrm{~N}_{6} \mathrm{~S}$ & 360.4 & 200 & 69.44 & $228-229$ \\
\hline 4 & EP 4 & $4-\mathrm{OMe}$ & $\mathrm{CH}_{3}$ & $\mathrm{C}_{20} \mathrm{H}_{18} \mathrm{~N}_{6} \mathrm{OS}$ & 390.4 & 220 & 76.92 & $216-218$ \\
\hline
\end{tabular}


RASĀYAN J. Chem.

Vol. 11 | No. 4 |1441 - 1450| October - December | 2018

\begin{tabular}{c|c|c|c|c|c|c|c|c}
\hline 5 & EP 5 & $4-\mathrm{OH}$ & $\mathrm{CH}_{3}$ & $\mathrm{C}_{19} \mathrm{H}_{16} \mathrm{~N}_{6} \mathrm{OS}$ & 376.4 & 200 & 73.17 & $250-252$ \\
\hline 6 & EP 6 & $4-\mathrm{CH}_{3}$ & $\mathrm{CH}_{3}$ & $\mathrm{C}_{20} \mathrm{H}_{18} \mathrm{~N}_{6} \mathrm{~S}$ & 374.4 & 210 & 81.55 & $231-232$ \\
\hline 7 & EP 8 & $4-\mathrm{F}$ & $\mathrm{CH}_{3}$ & $\mathrm{C}_{19} \mathrm{H}_{15} \mathrm{FN} 6$ & 378.4 & 180 & 84.65 & $227-229$ \\
\hline 8 & EP 9 & $4-\mathrm{Cl}$ & $\mathrm{CH}_{3}$ & $\mathrm{C}_{19} \mathrm{H}_{15} \mathrm{ClN}_{6} \mathrm{~S}$ & 394.8 & 180 & 81.21 & $266-268$ \\
\hline 9 & EP 10 & $3-\mathrm{NO}_{2}$ & $\mathrm{CH}_{3}$ & $\mathrm{C}_{19} \mathrm{H}_{15} \mathrm{~N}_{7} \mathrm{O}_{2} \mathrm{~S}$ & 405.4 & 190 & 80.24 & $215-217$ \\
\hline
\end{tabular}

aReaction conditions: 3-(4-nitrophenyl)-1-phenyl-1H-pyrazole-4-carbaldehyde (1mmol) with 4-amino-5-methyl-4H1, 2, 4-triazole-3-thiol (1 mmol) in presence of acetic acid in methanol

b Isolated yield

\section{Pharmacology}

The antibacterial evaluation of synthesized compounds revealed that some of the screened compounds exhibited excellent inhibition at $5 \mu \mathrm{g} / \mathrm{ml}$ concentration. The antibacterial evaluation revealed that among the screened compounds, EP 2 and EP 8 exhibit excellent activities against all the tested bacterial strains like E.coli., Klebsiella spp., Proteus spp., Acinetobacter spp. and Enterobacter spp.(Fig.-1).The remaining compounds show antibacterial activity at higher concentrations. All the results obtained are shown in Table-3. The anti-inflammatory activity of synthesized compounds is shown in Fig.-2. Compound EP 10 showed excellent activity at $1 \mathrm{mM}$ and compounds EP 3, EP 6, and EP 8 showed moderate activity. Anti-oxidant activity of synthesized compounds is shown in Fig.-3, compound EP 5 exhibited excellent activity while EP 8 exhibited moderate activity at $1 \mathrm{mM}$.

\section{Antibacterial Studies}

The synthesized compounds were dissolved in DMSO, so as to ensure that the solvent had no effect on the bacterial growth or the enzymatic activity. Negative control tests were also performed using DMSO at the same concentrations. Five different bacteria Viz. E.coli., Klebsiella spp., Proteus spp., Acinetobacter spp. and Enterobacter spp.were evaluated using agar gel diffusion method. The inhibitory effect of all compounds on in-vitro growth of bacteria was evaluated using agar diffusion method (cup and plate method $)^{30}$,by measuring the zone of inhibition on agar plates at three different concentrations $1.25 \mu \mathrm{g} / \mathrm{ml}$, $2.5 \mu \mathrm{g} / \mathrm{ml}$ and $5.0 \mu \mathrm{g} / \mathrm{ml}$. DMSO was used as a solvent control. All plates were incubated at $37 \pm 0.5^{\circ} \mathrm{C}$ for 24 hours. The zones of inhibition of compounds were measured using mm scale. Streptomycin was used as reference drug and treated similarly for determination of zone of inhibition and the results are shown in Table-3. The graphical representation of the antibacterial activity of EP 2 against pathogenic bacteria is shown in Fig.-1.

Table-3: Antibacterial Activity Data of Derivative of 4-\{[(Z)-(1,3-diphenyl-1H-pyrazol-4-yl)methylidene] amino $\}$ 5-methyl-4H-1,2,4-triazole-3-thiols

\begin{tabular}{|c|c|c|c|c|c|c|c|c|c|c|}
\hline \multirow{2}{*}{$\begin{array}{l}\text { Name of } \\
\text { Organism }\end{array}$} & \multirow{2}{*}{$\begin{array}{c}\text { Concentrations } \\
(\mu \mathrm{g} / \mathrm{ml})\end{array}$} & EP 1 & EP 2 & EP 3 & EP 4 & EP 5 & EP 6 & EP 8 & EP 9 & EP 10 \\
\hline & & \multicolumn{9}{|c|}{ Zone of Growth Inhibition (mm) } \\
\hline \multirow{4}{*}{ Proteus spp. } & Control & - & + & - & + & - & - & + & + & + \\
\hline & 1.25 & + & ++ & + & ++ & ++ & ++ & ++ & + & ++ \\
\hline & 2.5 & ++ & +++ & + & +++ & ++ & +++ & +++ & ++ & +++ \\
\hline & 5.0 & ++ & ++++ & + & ++++ & +++ & ++ & ++++ & +++ & +++ \\
\hline \multirow{4}{*}{ E. coli } & Control & - & - & - & - & + & - & - & - & - \\
\hline & 1.25 & + & ++ & ++ & ++ & + & ++ & ++ & + & ++ \\
\hline & 2.5 & ++ & +++ & ++ & +++ & ++ & +++ & +++ & ++ & +++ \\
\hline & 5.0 & +++ & ++++ & ++ & +++ & +++ & +++ & ++++ & +++ & +++ \\
\hline \multirow{4}{*}{$\begin{array}{l}\text { Klebsiella } \\
\text { spp. }\end{array}$} & Control & - & - & - & - & - & - & - & + & + \\
\hline & 1.25 & - & ++ & - & ++ & - & ++ & ++ & + & ++ \\
\hline & 2.5 & ++ & +++ & ++ & +++ & ++ & ++ & +++ & + & +++ \\
\hline & 5.0 & ++ & +++ & +++ & +++ & +++ & +++ & ++++ & +++ & +++ \\
\hline \multirow{3}{*}{$\begin{array}{c}\text { Acinetobacter } \\
\text { spp. }\end{array}$} & Control & - & - & - & - & - & - & + & + & - \\
\hline & 1.25 & + & ++ & + & ++ & ++ & ++ & ++ & + & ++ \\
\hline & 2.5 & ++ & +++ & ++ & +++ & +++ & +++ & +++ & ++ & ++ \\
\hline
\end{tabular}


RASĀYAN $J$. Chem.

Vol. 11 | No. 4 |1441 - 1450| October - December | 2018

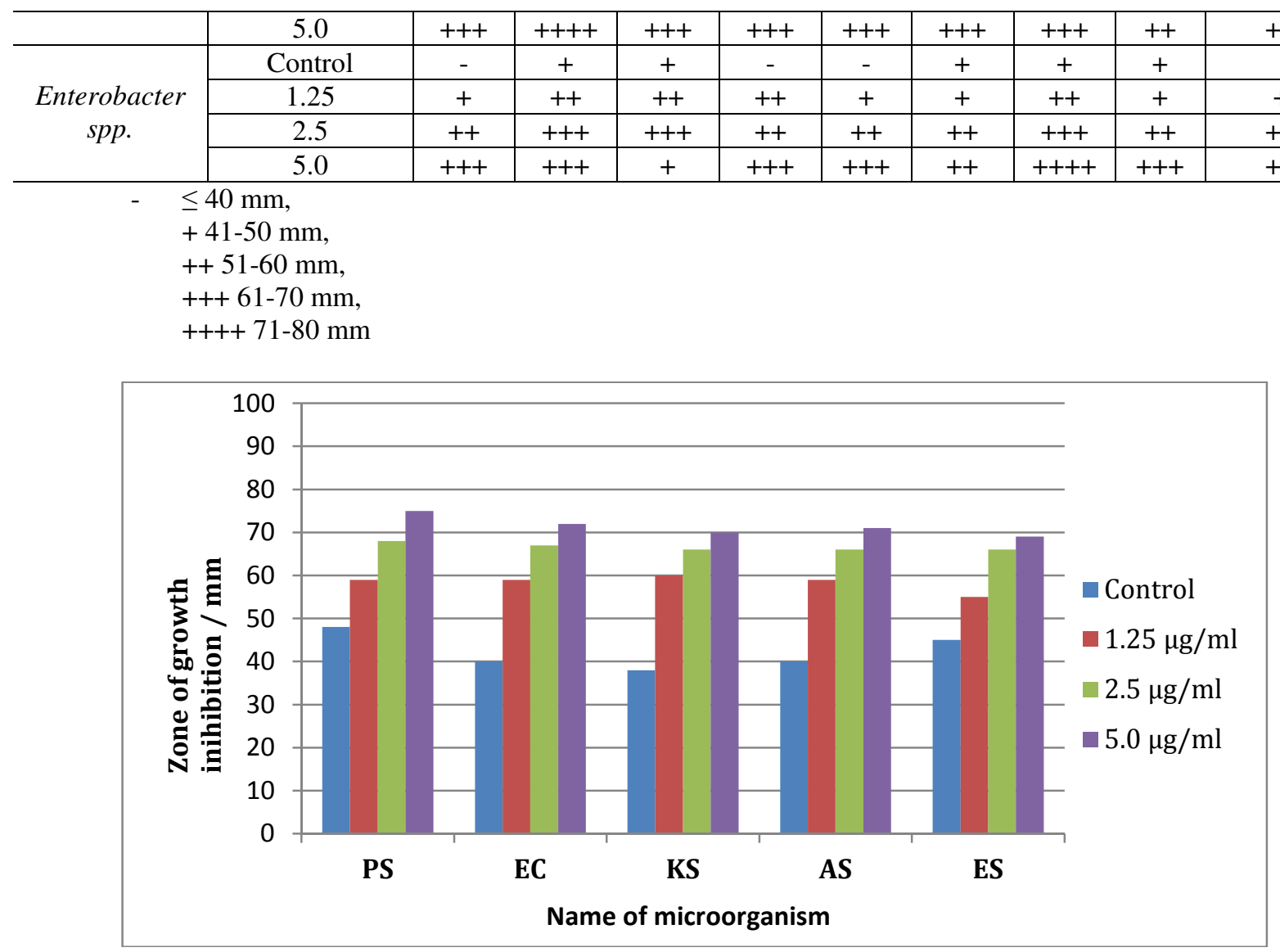

Fig.-1: Antibacterial Evaluation of EP 2 against Pathogenic Bacteria

$\mathrm{PS}=$ Proteus spp., EC=E.coli, KS=Klesiella spp., AS=Acinetobacterspp, ES=Enterobacter spp.Fig.-1 Antibacterial activity of 4-[(Z)-\{[3-(4-bromophenyl)-1-phenyl-1H-pyrazol-4 yl]methylidene $\}$ amino]-5methyl-4H-1,2,4-triazole-3-thiols

\section{In Vitro Anti-inflammatory Activity}

The anti-inflammatory activity was measured by protein denaturation method. The reaction mixture (10 $\mathrm{mL}$ ) consisted egg albumin (of $0.4 \mathrm{~mL}$, from fresh hen egg), phosphate buffered saline (5.6 mL, PBS, pH 6.4) and synthetic derivatives $(4 \mathrm{~mL}, 1 \mathrm{mM})$. A similar volume of double-distilled water was used as a control. Then the mixtures were incubated at $\left(37^{\circ} \mathrm{C} \pm 2\right)$ in an incubator for 15 minutes and then heated at $70{ }^{\circ} \mathrm{C}$ for 5 minutes. After cooling, the absorbance was measured at $660 \mathrm{~nm}$. Diclofenac sodium ( $\left.1 \mathrm{mM}\right)$ was used as reference drug and processed similarly for determination of absorbance. The percentage inhibition of protein denaturation was calculated by using the formula,

Where,

$$
\% \text { Inhibition }=100 \mathrm{x} \frac{\mathrm{Vt}}{\mathrm{Vc}-1}
$$

$\mathrm{V}_{\mathrm{t}}=$ absorbance of the test sample.

$\mathrm{V}_{\mathrm{c}}=$ absorbance of control.

\section{Antioxidant Activity}

The molecule 1, 1-diphenyl-2-picrylhydrazyl (a,a-diphenyl-bipicrylhydrazyl; DPPH) is characterized as a stable free radical by virtue of the delocalization of the electron over the molecule as a whole so that the molecule does not dimerize, as would be the case with most other free radicals. The delocalization of electron also gives rise to the deep violet color, characterized by an absorption band in ethanol solution centered at about $517 \mathrm{~nm}$. When a solution of DPPH is mixed with the substrate $(\mathrm{AH})$, it donates a 
hydrogen atom, and gives rise to the reduced form with the loss of this violet color. The ability of synthesized compounds to scavenge DPPH radical was assessed using Kumar et al ${ }^{31}$ and Manzocco et al ${ }^{32}$ method with modification. Briefly, $1 \mathrm{ml}$ of synthesized compound $(1 \mathrm{mM})$ was mixed with DPPH (3.0 $\mathrm{mL}, 0.5 \mathrm{mmol} / \mathrm{L}$ in methanol), the resultant absorbance was recorded at $517 \mathrm{~nm}$ after 30 minutes incubation at $37^{\circ} \mathrm{C}$. The percentage of scavenging activity was derived using the formula,

Where,

$$
\% \text { Inhibition }=\frac{\text { A control }- \text { A sample }}{\text { A control }} \times 100
$$

A control - absorbance of DPPH

A sample - absorbance of the reaction mixture (DPPH with sample).

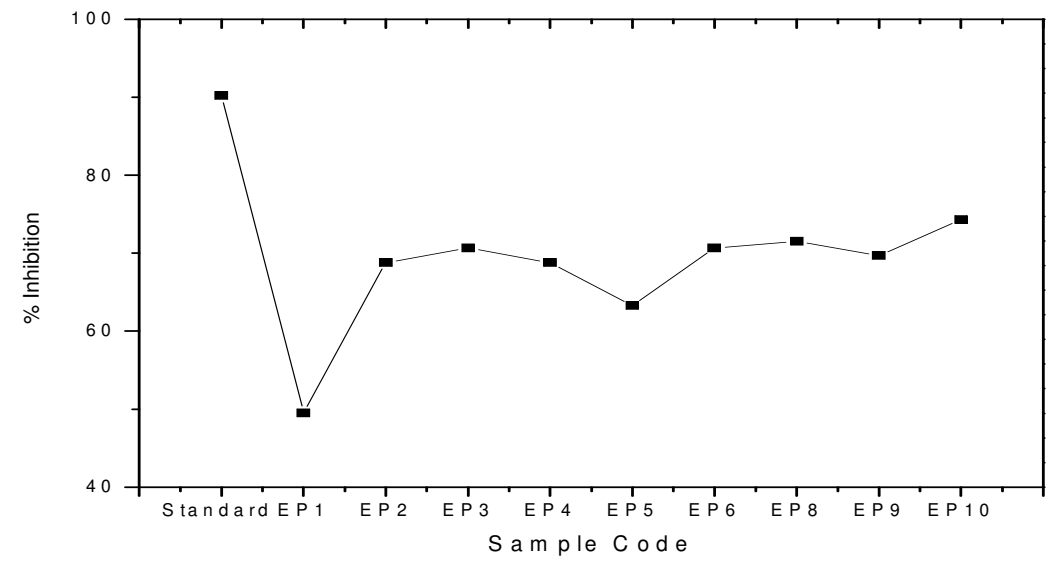

Fig.-2: Graphical representation of In-vitro Anti-Inflammatory Activity for Derivative of 4-amino-5-methyl-4H-

1,2,4-triazole-3-thiol at (1 $\mathrm{mM})$

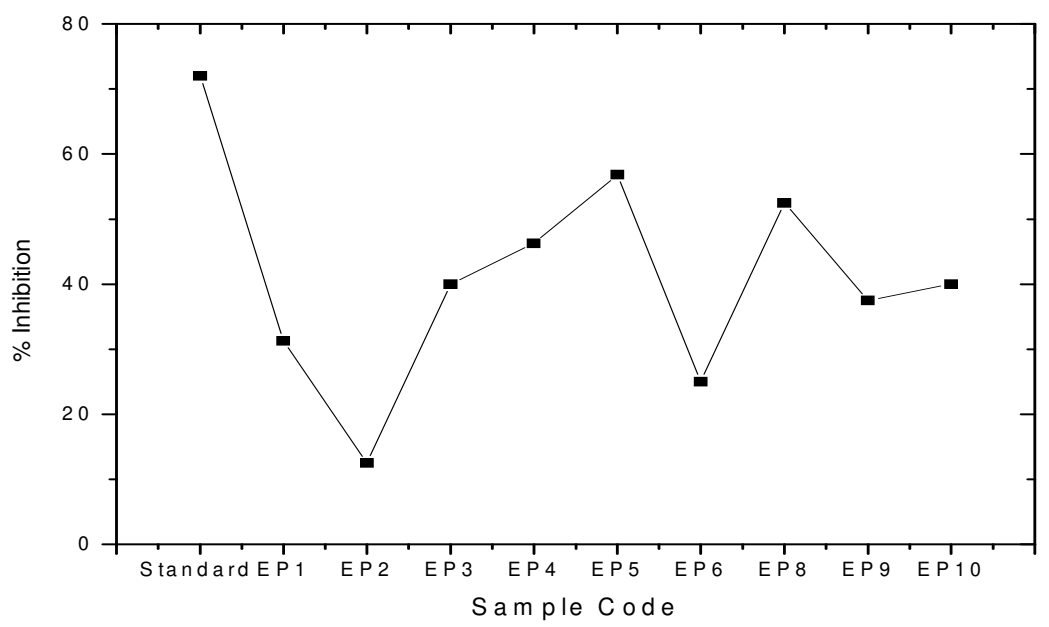

Fig.- 3: Graphical representation of In-vitro Antioxidant Activity for Derivative of 4-Amino-5-methyl-4H-1,2,4-

\section{Molecular Modeling}

triazole-3-thiol at $(1 \mathrm{mM})$

The virtual analysis was employed to determine the mode of action for the antimicrobial potential of synthesized triazole derivatives. Docking analysis was performed on bioproducts module of V life MDS 4.3. Crystal structure of DNA gyrase $B$ (PDB ID5JL3) was downloaded from free protein database www.rcsb.org. Protein refinement was performed on bioproducts module via removal of water molecules 
RASĀYAN $J$. Chem.

Vol. 11 | No. 4 |1441 - 1450| October - December | 2018

and the addition of native hydrogen atoms. Structures of molecules understudy were drawn using 2D molecule builder and converted into the 3D structure using a 3D converter and optimized using molecular force field till gradient value of $0.001 \mathrm{kcal} /(\mathrm{mol} \AA)$ is reached. Grip-based docking simulations were performed keeping protein structure rigid and ligand structure flexible. Binding modes of EP 5 and EP 10 are shown in Fig.-4 and Fig.-5

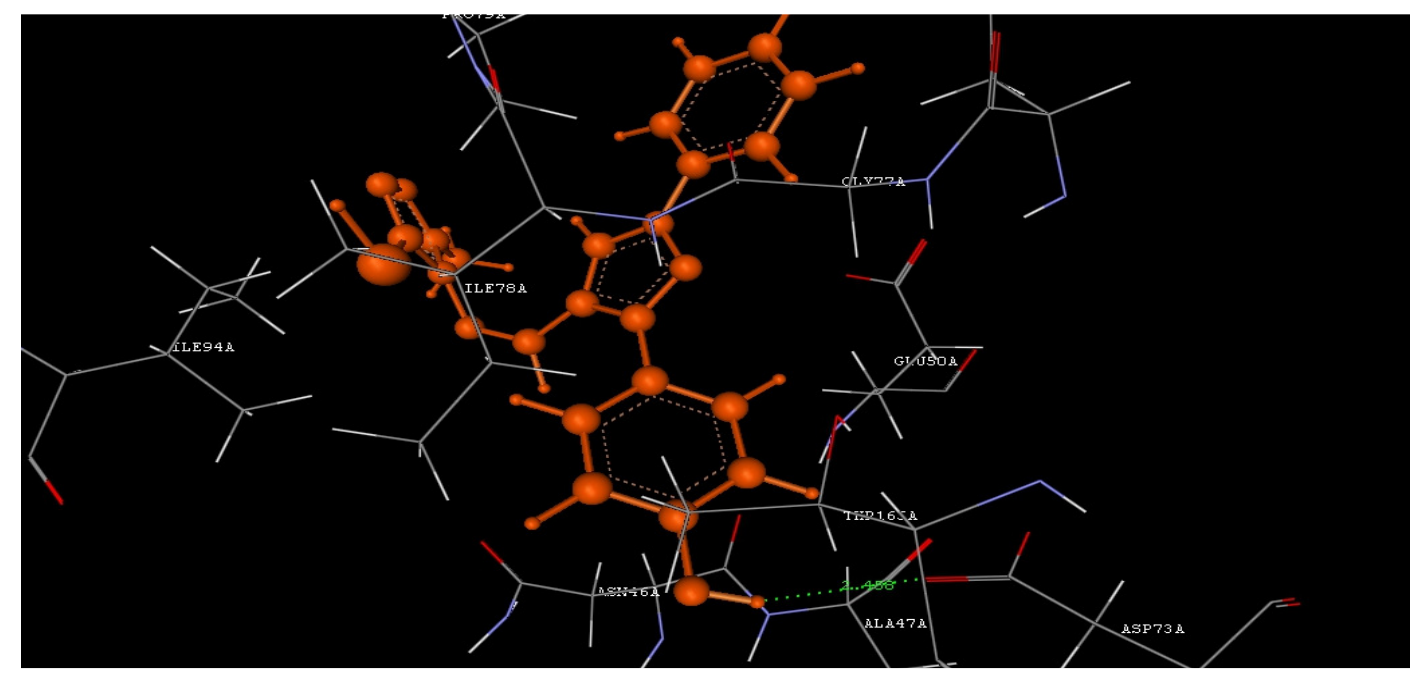

Fig.-4: Binding Mode of EP 5: (4-(4-\{(Z)-[(3-methyl-5-sulfanyl-4H-1,2,4-triazol-4yl)imino] methyl $\}-1-$ phenyl-1Hpyrazol-3-yl)phenol)

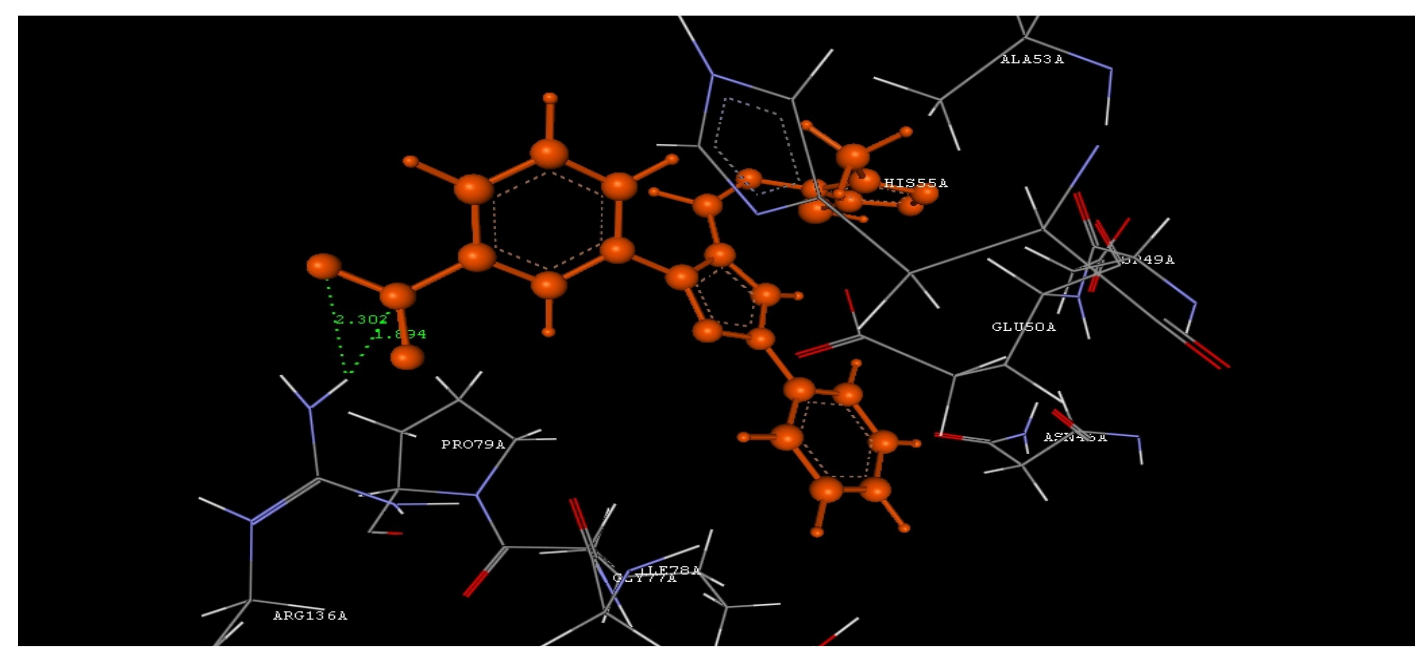

Fig.-5: Binding Mode of EP10: (5-methyl-4-[(Z)-\{[3-(3-nitrophenyl)-1-phenyl-1H-pyrazol-

4yl]methylidene amino]-4H-1,2,4-triazole-3-thiol)

\section{Molecular Modeling Analysis}

In order to ascertain the mode of action of synthesized triazole derivatives, molecular modeling was performed on DNA gyrase B. All the nine synthesized derivatives were docked in similar binding site showing the similar mode of action. Virtually most active molecule EP 10 showed the total binding energy of $-58.02 \mathrm{kcal} / \mathrm{mol}$ and showed critical hydrogen bond interaction with ARG136 (1.8 A ), hydrophobic interactions with GLU50, ALA53 and vander Waal's interactions with ASN46, ALA47, GLU50, ASP73, ARG76, ILE78, PRO79, ILE94, and THR165. EP 5 showed the total binding energy of $66.52 \mathrm{kcal} / \mathrm{mol}$, and hydrogen bond interaction with ASP73 (2.4 ̊̊), hydrophobic interaction with ILE94 and vander Waal's interactions with ASN46, ASP49, GLU50, ALA53, HIS55, GLY77, ILE78, PRO79, 
RASĀYAN J. Chem.

Vol. 11 | No. 4 |1441 - 1450| October - December | 2018

ARG136, THR165. EP 9 is having a binding energy of $-60.67 \mathrm{kcal} / \mathrm{mol}$, with critical interaction with ASP73 via hydrogen bond formation and with ILE94 via hydrophobic interaction.<smiles>[R]c1ccc(C(C)=O)cc1</smiles>

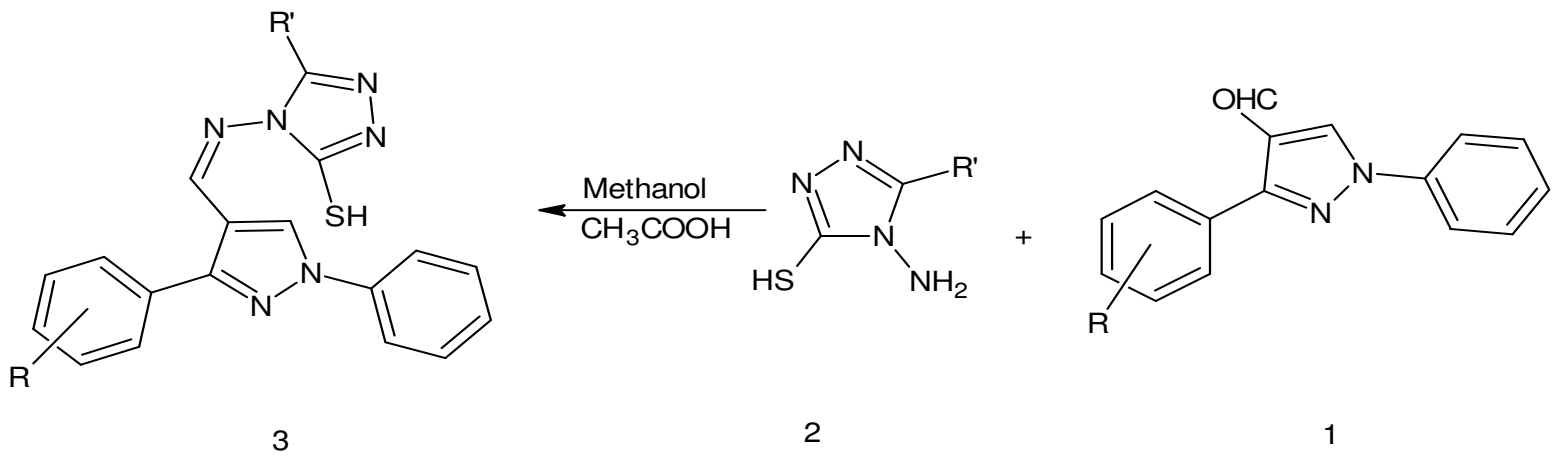

Scheme-1: Synthetic Pathway to Derivatives of 4-amino-5-methyl-4H-1, 2, 4-triazole-3-thiol

\section{CONCLUSION}

A series of some 4-\{[(Z)-(1, 3-diphenyl-1H-pyrazole-4-yl) methylidene]amino $\}-5$-methyl-4H-1,2,4triazole-3-thiols were synthesized and characterized by ${ }^{1} \mathrm{H}$ NMR, ${ }^{13} \mathrm{C}$ NMR, IR and mass spectroscopic techniques. All the synthesized compounds were evaluated for their antibacterial, anti-inflammatory and anti oxidant activities and their zones of inhibition were determined. Antimicrobial activity study suggested that compound EP 2 and EP 8 having $p$-bromo and $p$-fluoro substitution respectively exhibited maximum inhibition against all the tested microorganisms. Similarly, compounds EP 4 and EP 10 having $p$-methoxy and m-nitro substituents also showed significant activity against microorganisms Citrobacter spp., E. coli, Klebsiella spp. All remaining compounds showed restrained inhibition. Compound EP 8 $(71.55 \%)$ and EP $10(74.31 \%)$ exhibit excellent anti-inflammatory activity while compound EP 5 (56.87 $\%)$ and EP 8 (52.50\%) exhibit good antioxidant activity.1, 2, 4-triazole nucleus is one of the energetic components present in all molecules contributing to the net biological activity of the synthesized compounds.

\section{ACKNOWLEDGMENT}

One of the authors (P R Kate) is thankful to CSIR-UGC New Delhi for financial support through UGCJRF fellowship. [File No. F. 11-2/2013(SA-II)]. Author(s) are also thankful to Principal, Karmaveer Bhaurao Patil Mahavidyalaya, Pandharpur and Principal, Shri Shivaji Mahavidyalaya, Barshi for providing necessary facilities.

\section{REFERENCES}

1. B. Kalluraya, B.Lingappa and N.S. Rai, Phosphorus, Sulfur and Silicon, 182, 1393(2007), DOI:10.1080/10426500601161049.

2. V. Padmavathi, P. Thriveni, S. G. Reddy and D. Deepti, Eur. J. Med. Chem., 43, 917(2008), DOI:10.1016/j.ejmech.2007.06.011.

3. M. Amir, H. Kumar and S. A. Javed, Eur. J. Med. Chem., 43, 2056(2008), DOI:10.1016/j.ejmech.2007.09.025.

4. K. Sztanke, T. Tuzimski, J. Rzymowska, K. Pasternak and M. Kandefer-Szersze, Eur. J. Med. Chem., 43, 404 (2008), DOI:10.1016/j.ejmech.2007.03.033.

5. C. Kus, G. A. Kilcigil, S. O”zbey, F. B. Kaynak, M. Kaya, T. Coban and B. C. Eke, Bioorg. Med. Chem., 16, 4294 (2008), DOI:10.1016/j.bmc.2008.02.077. 
RASĀYAN J. Chem.

Vol. 11 | No. 4 |1441 - 1450| October - December | 2018

6. Z. Y. Zhang and Xiago-Wen, Heterocycles, 48, 561(1998), DOI: 10.3987/REV-97-489.

7. A. M. Isloor, B. Kalluraya, M. Rao and A. M. Rahiman, J. Saudi. Chem. Soc., 4, 265 (2000).

8. B. Kalluraya, A. M. Isloor and S. Shenoy, Indian J. Heterocycl. Chem., 11, 159 (2001).

9. B. Kalluraya, A. M. Isloor, F. V. Priya and R. L. Jagadeesha, Indian J. Heterocycl .Chem., 13, 245 (2004), http://eprints.uni-mysore.ac.in/id/eprint/3764.

10. N. J. Thumar, M. P. Patel, J. Med. Chem. Res., 21, 751(2012), DOI: 10.1007/s00044-011-9693-2.

11. J. Peto, Nature, 411,390(2001), DOI: 10.1038/35077256.

12. I. Chopra, C. Schofield, M. Everett, A. O’Neill, K. Miller, M. Wilcox, J. M. Fre`re, M. Dawson, L. Czaplewski, U. Urleb and P. Courvalin, Lancet Infect. Dis., 8,133(2008), DOI: 10.1016/s14733099(08) 70018-5.

13. A. A. Bekhit, M. A. Ashour, S. A. Ghany, A. E. Bekhit and A. M. Baraka, Eur. J. Med. Chem., 43, 456(2008), DOI:10.1016/j.ejmech.2007.03.030

14. P. T. Chovatia, J. D. Akabari, P. K. Kachhadia, P. D. Zalawadia and H. S. Joshi, J. Serb. Chem. Soc., 71, 713(2007), DOI: 10.2298/JSC0607713C.

15. I. Damljanovic, M. Vukicevic, N. Radulovic, R. Palic, E. Ellmerer, Z. Ratkovic, M. D. Joksovic and R. D. Vukicevic, Bioorg. Med. Chem. Lett., 19, 1093(2009), DOI:10.1016/j.bmcl.2009.01.006.

16. A. I. Hashem, S. A. Youssef, K. A. Kandeel and S. I. Abou-Elmagd, Eur. J. Med. Chem., 42, 934(2007), DOI:10.1016/j.ejmech.2006.12.032.

17. P. Rathelot, N. Azas, H. El-Kashef, F. Delmas, C. D. Giorgio, P. Timon-David, J. Maldonado and P. Vanelle, Eur. J. Med. Chem., 37, 671(2002), DOI: 10.1069/s0223-5234 (02) 01388-0.

18. M. D. Joksovic, V. Markovic, Z. D. Juranic, T. Stanojkovic, L. S. Jovanovic, I. S. Damljanovic, K. M. Szecsenyi, N. Todorovic, S. Trifunovic and R. D. Vukicevic, J. Org. met. Chem., 694, 3935(2009), DOI:10.1016/j.jorganchem.2009.08.013

19. A. H. Abadi, A. H. Eissa and G. S. Hassan, Chem. Pharm. Bull., 51, 838(2003), DOI: $10.1248 / \mathrm{cpb} .51 .838$

20. S. C. Shetty and V. C. Bhagat, Asian J. Chem., 20, 5037 (2008).

21. X. Collin, A. Sauleau and J. Coulon, Bioorg. Med. Chem. Lett., 13, 2601(2003), DOI: 10.1016/S0960-894X(03)00378-0.

22. O. Bekircan and H. Bektas, Molecules, 11, 469(2006), DOI: 10.3390/11060469.

23. S. A. Deodware, D. J. Sathe, P. B. Choudhari, T. N. Lokhande and S. H. Gaikwad, Arab. J. Chem., 10, 262(2017), DOI: org/10.1016/j.arabjc.2016.09.024

24. A. B. Shaikh, U. B. Barache, T. N. Lokhande, G. S. Kamble, M. A. Anuse and S. H. Gaikwad, Rasayan J. Chem., 10(3), 967(2017), DOI: 10.7324/RJC.2017.1031804

25. A. B. Shaikh, U. B. Barache, M. A. Anuse and S. H. Gaikwad, S. Afr. J. Chem., 69, 157(2016), DOI: 10.17159/0379-4350/2016/v69a19

26. U. B. Barache, A. B. Shaikh, T. N. Lokhande, M. A. Anuse, G. S. Kamble, V. M. Gurame, S. H. Gaikwad, Journal of Environmental Chemical Engineering, 5, 4828(2017), DOI: 10.1016/j.jece.2017.09.021

27. U. B. Barache, A. B. Shaikh, T. N. Lokhande, G. S. Kamble, M. A. Anuse, S. H. Gaikwad, SpectrochimicaActa Part A: Molecular and Biomolecular Spectroscopy, 189, 443(2018), DOI: 10.1016/j.saa.2017.08.054

28. A. Q. Ather, M. N. Tahir, M. A. Khan, K. Mehmood and F. Chaudhary, Acta Cryst. E, 66, 3170(2010), DOI: $10.1107 /$ S1600536810045630

29. S. H. Gaikwad, T. N. Lokhande and M. A. Anuse, Ind. J. Chem., 44A, 1625(2005), http://hdl.handle.net/123456789/18089.

30. A. L. Barry, Illus. Lea. and Febiger, Philadeliphia, USA, 180, (1976).

31. S. K. Ramanathan, Journal of Complementary and Integrative Medicine, 5(1), 1(2008), DOI: 10.2202/1553-3840.1125.

32. L. Manzocco, M. Anese and M. C. Nicoli., Lebensm.-Wiss. u.-Technol., 31, 694(1998), DOI: 10.1006/fstl.1998.0491.

[RJC-3080/2018] 